\title{
The Impact of Registration of a Single Color as a Trademark on Unfair Competition
}

\author{
-A Comparative Study-
}

\author{
Awara A. Ahmed \\ Department of Law, College of Law, University of Sulaimani, Sulaimani, Kurdistan Region -Iraq \\ Department of Law, College of Law and politics, University of Human Development, Sulaimani, Kurdistan Region -Iraq
}

\begin{abstract}
The application for registration of non-traditional signs as trademarks has been increasing over the last two decades. "Single Color" is one of those non-traditional signs which has been applied for, especially in the U.K and U.S.A. Similarly, the Iraqi Trademark Law has allowed registration of colors as a trademark. However, the case law argues whether a single color may satisfy the requirements for registration of a trademark. On the other hand, the risks of color exhaustion and the anticompetitive effects of color monopolies are the main concerns on allowing the registration of single color trademarks. Therefore, protection of such trademarks from unfair competition might be difficult.
\end{abstract}

Index Terms - Color exhaustion, unfair competition, single color, trademarks.

\section{INTRODUCTION}

Trademarks are distinctive signs which indicate the origin or manufacturer of products on which they are applied; it is used as an intellectual property by any individual or business organization (Nigam, Garg, Tripathi, 2011, p.01). The concept of trademark is not a new one. It has been used since ancient times. For instance, in Roman times, the potters put their names on the potteries in order to convey a message about the origin of the potter. In the majority of situations, legal protection was granted by using the mark instead of formally by the state. Then, the system of registration for trademarks was introduced. For example, in the UK, the Trademark Act was introduced in 1875 which provided for a system of Trademarks Registry (Torremans, 2010, p. 385-386).

The subject of trademark in the European Union (EU) is regulated through two regulations; first, the Trademark Directive (Directive, 2008) (the EU Directive), to harmonize national laws relating to trademarks throughout the European Community; second, and the Council Regulation on the Community trademark (the EU Regulation) (Council Regulation, 2009).
Article 02 of the EU Directive sets out that 'A trademark may consist of any sign capable of being represented graphically, particularly words, including personal names, designs, letters, numerals, the shape of goods or of their packaging, provided that such signs are capable of distinguishing the goods or services of one undertaking from those of other undertakings'. However, even if a mark meets these requirements, it shall not be registered or declared valid if there is a ground for refusal of registration (see Article 03 (1) of the Directive). Identical provisions are stated in the United Kingdom Trademark Act 1994 (TMA 1994).

In Iraq, the trademark registration is regulated by Trademark and Geographical Indications Law No. 21 of 1957. The Law was originally titled as "Trademark and Descriptions Law"; however, in response to the new requirements in the trademarks era, the law was amended in 2004 by Coalition Provisional Authority (CPA) according to which it was renamed to the "Trademark and Geographical Indications Law" (Section 1/1 of the CPA order). Likewise the EU Directive, the Iraqi law defines the trademark and it also brings grounds for refusal of registration. It defines trademark as "Any sign, or any combination of signs, capable of distinguishing the goods of one undertaking from those of other undertakings,... Such signs, in particular words including personal names, letters, numerals, figurative elements and colors as well as any combination of such signs, shall be eligible for registration as trademarks." (Article 01 of the Iraqi Trademark Law).

The Iraqi law explicitly allows registration of colors as a trademark. However, the definition brings the word of "colors" in plural. Therefore, it is not clear whether "a single color" is accepted to be registered as trademark.

\section{Research Objectives}

Registration on non-traditional trademarks has been controversial. "Single Color" is one of these marks which have led to arguments in the EU case law. Similarly, the Iraqi legislation has allowed registration of colors as trademark. This

Journal of University of Human Development

Volume 6 No. 1(2020); DOI: 10.21928/juhd.v6n1y2020.pp27-34

Regular research paper: Received 12 January 2020; Accepted 16 February 2020; Published 19 February 2020

Corresponding author's e-mail: awara.ahmed@univsul.edu.iq

Copyright (02020 Awara Azad Ahmed. This is an open access article distributed under the Creative Commons Attribution License

(CC BY-NC-ND 4.0) 
paper will shed the light on the capability of single color registration under the EU and Iraqi law.

\section{Research Problem}

The issue of the registration of color marks is somewhat controversial and problematic. This paper's thesis is about whether "a single color" is accepted to be registered as trademark. If so, how it would correlate with competition between undertakings.

\section{Research Methodology}

In conducting the study, analytical comparative method has been adopted; capability of registration of single color as a trademark has been analyzed with EU regulations, case law, and Iraqi legislations. Different applicable legislations have been compared.

This issue will be discussed below and the effects of allowing the registration of single colors on competition will be examined. In so doing, the focus will be on legal provisions in the EU and Iraq, with EU and US case law in the area.

\section{COLOR TRADEMARKS}

Recent developments in the trademark law have led to extend registration and legal protection to non-traditional marks such as shapes, scents, sound and color marks, even though trademarks were generally composed of words and logos. The World Trade Organization ("WTO") Agreement on TradeRelated Aspects of Intellectual Property Rights (TRIPs 1995) in Article 15(1), explicitly states that 'combinations of colors' shall be capable of constituting a trademark.

Regarding color registration as a trademark, the EU Directive and the Regulation do not refer to color or combination of colors as a sign for the registration purposes. However, as stated in recital 8 of the EU Directive, the list of marks in Article 02 of the Directive is not exhaustive and it is by way of example. It might be said that this matter is left for national legislators. They may insert single color or color combination in the list when they implement the Directive. On the contrary, the Iraqi Trademark Law explicitly allows registration of colors as trademarks.

Under the EU Directive and the Regulation, regardless of not referring to color registration, accepting or refusing registration of a color is not consistent and it is examined on case-by-case basis. It can be noticed from the Directive, in order to register a mark as a trademark, it must be a sign which is capable of being represented graphically and has distinctive character. These conditions will be discussed below. Moreover, in addition to these conditions, there should not be a ground for refusal. Granting protection for color marks or single color marks is subject to the same test as other marks.

\section{REQUIREMENTS FOR REGISTRATION OF A TRADEMARK}

As mentioned above, according to Article 02 of the EU Directive, a mark must be: (1) a sign; (2) capable of being represented graphically; (3) capable of distinguishing goods of one undertaking from those of other undertakings. These conditions are applied on all categories of trademarks, including color marks. The Iraqi Trademark Law has also set out required conditions for registration of trademarks. The requirements under the EU and Iraqi law will be examined below.

\section{A. A sign}

Article 03(1)(a) of the EU Directive states that if a sign cannot constitute a trademark, it cannot be registered. Therefore, a color mark, like other marks, must consist of a sign.

Case law has also tested whether colors constitutes a sign. In Libertel Groep BV v. Benelux-Merenbureau (Groep BV v. Merenbureau, 2003, ECR I-3793), the claimant made an application to register the color orange per se as a trademark for certain telecommunications services. In the space for reproducing the trademark, they put an orange rectangle and in the space for describing the trademark, the word 'orange' without reference to any color code. The Benelux Office for Intellectual Property refused the registration on the ground that the proposed mark 'the color' lacked distinctive character. Therefore, the applicant appealed and the Dutch court remitted the issue to the Court of Justice of the European Union (CJEU). In that case, it was held that a color can constitute "a sign" for the purposes of the Directive.

Furthermore, in Societe des Produits Nestle SA v Cadbury UK Ltd (Nestle SA v. Cadbury Ltd, 2012, EWHC 2637), an application was filed by Cadbury for registration of the color purple, Pantone $2685 \mathrm{C}$, as a trademark applicable to the surface of the packaging of the goods (chocolate products). After showing that the color acquired a distinctive character in accordance with Section 3(1) (b) of the TMA 1994, the registration was allowed. Then, Nestle appealed the decision taken by the UK Intellectual Property Office on a number of different grounds. In the High Court, Nestle claimed that the mark was not a 'sign' capable of being represented graphically for the purpose of Section 3(1) (a). However, the court rejected that argument and held that the mark can constitute a sign, and the registration was therefore held to stand.

The Iraqi Trademark Law has brought this requirement as well. In defining trademark, it clearly requires the trademark must be a sign or signs (Article 01 of the Iraqi Trademark Law).

\section{B. Graphic representation}

Capability of being represented graphically is another requirement for a mark in order to be registered as a trademark. The origin of this requirement may refer to the TRIPS Agreement in which it provides that 'Members may require, as a condition of registration, that signs be visually perceptible' (Article 15(1) of TRIPS Agreement). This condition is also provided for in the Community legislation, in Article 02 of the Directive and Article 04 of the Regulation. Accordingly, if a sign cannot be represented graphically, it leads to the refusal of its registration as a trademark.

In the Libertel case, the CJEU applied the Sieckmann test which also concerned another non-traditional trademark, a scent mark (Sieckmann v. Deutsches Patent- und Markenamt, 2002, ECR I-11737). The court held that the graphical representation must be clear, precise, self-contained, easily 
accessible, intelligible, durable and objective. Therefore, it stated that a mere sample of color does not constitute graphic representation because it may deteriorate with time and it may change slightly depending on the background on which it is printed or against which it is put. Further, it was pointed out that a verbal description of a color or a sample of a color combined with description in words of that color may constitute graphic representation and then passes the test provided that this description is clear, precise, self-contained, easily accessible, intelligible, durable and objective (Groep BV v. Merenbureau, 2003, ECR I-3793).

However, describing the shade of the color in words may not be sufficient. The OHIM Board of Appeal, in the Orange case (Orange, 1998, ETMR 337), stated that a mere written description of the color 'orange', without any reference to a code number and without attaching to the application any explicit figurative reproduction of the color, is not sufficient to fulfill the requirement of graphical representation. It also went further, saying that 'since an uncountable number of different color shades, ranging in the specific case from dark to light and from the yellowish to the reddish tones, are conceivable which would all fall under the wide generic term "orange"...' (Orange, 1998, ETMR 337).

In Cadbury case (Nestle SA v. Cadbury Ltd, 2012, EWHC 2637), one of the grounds of the claim by Nestle was that the sign was not capable of being represented graphically. The court conformed to the Libertel criteria and held that using the word 'predominant' in the description section of the application for representation of the color on the goods it sought to cover did not 'introduce any more vagueness or uncertainty than is already present and acceptable in a trademark registration of this kind'. Therefore, it was held that Cadbury's registration is capable of being a sign and represented graphically.

Contrary to the EU regulation, under the Iraqi law there is not such place for argument as the law explicitly allows registration of signs which are not graphically represented. Article 01 of the amended law states "[s]igns need not be visually perceptible in order to be eligible for protection as trademarks." It shall be noted that this approach was taken by the amendment, while the origin version of the law had not referred to the visual representation.

Therefore, it can be said that color marks, like other marks, can be represented graphically for the purpose of the registration.

\section{Distinctiveness}

Capability of distinguishing is an essential prerequisite to grant trademark protection (Torremans, 2010, p. 396). This requirement is provided for by the Trademark Directive and it is empathized by the courts. A trademark which is devoid of any distinctive character cannot be registered in accordance with Article 03(1)(b) of the Directive because it cannot inform the consumer about the origin of the products. Therefore, consumers will not be able to distinguish between products from a trader and similar products from other traders.

In Kabushiki Kaisha v. Metro-Goldwyn-Mayer Inc, the Court of Justice of the European Union (CJEU) held that the essential function of a trademark is to enable the consumer or the end user to identify the origin of the product without any confusion and to distinguish the product from other products that have another origin (Kaisha v. Mayer Inc., 1998, ECR I05507).

One of the main issues relating to a color per se mark as one of the non-traditional trademarks is that whether a color can perform the function of trademark to inform the consumer about the origin of the product or service to which the mark is applied; in other words, whether consumers assume having a link between the color and a certain goods or services. In most cases, the refusal of registration of color trademarks is based on a lack of distinctive character.

It is argued that it is highly unusual that purchasers identify a product by depending on a non-traditional mark only (LaLonde, Gilson, 2011, p. 07). In particular, colors alone cannot constitute an independent source for identification and mere association does not mean that a color is functioning as a trademark (Bartow, 2009, p. 263). The CJEU, in 2010, denied registration of the color black 'black matt' and the color gold 'gold matt' covering a wine bottle as trademarks. This is because, in the court's view, the marks lack distinctiveness and they are not significantly different from surfaces which are usually used in the wine industry. (Freixenet, SA v. OHIM, 2010, T-110/08).

However, it is submitted that color per se can have a distinctive character. Distinctiveness can be inherent or acquired. The latter is achieved by the use made of the sign. In Libertel, the CJEU held that a color may have a distinctive character within the meaning of Article 03 of the Directive. It was also held that even if a color per se did not have distinctive character inherently, it could acquire such character following the use made of it. For instance, Cadbury has used the color purple since 1914 and therefore, it was found that the color has acquired a distinctive character through use.

In the Orange Ltd, the applicant sought to register the color orange as a community trademark without more specification, such as a Pantone number, to define the shade of the color. The Third Board of Appeal of OHIM stated that a single color will usually lack distinctiveness or be precluded by the absolute grounds for refusal (e.g. descriptive or common usage) unless the mark is restricted to particular products or the applicant shows that it has become distinctive through use (Orange, 1998, ETMR 337).

Similarly, under the Iraqi Trademark Law a sign must be distinctive for the purpose of registration, whether it has distinctive character inherently or acquired through use. The law, in two clauses, states that " $[w]$ here signs are not inherently capable of distinguishing the relevant goods or services, registrability will depend on distinctiveness acquired through use."(Article 01 and 5.1). It is worth to note that this clause was added to the law by the CPA amendment order no. 80; before the amendment, the law in no way referred to distinctiveness acquiring (Compare Article 05 of law before and after the amendment). As the result, the Iraqi law has been amended so that it would be consistent with the requirements in other countries and reflecting new changes in the trademark era. It shall be noted that there are other requirements for a sign to be registered as a trademark under Article 05 of the law, however such requirements are beyond of this paper's subject. 
Therefore, it might be said that when a color mark fulfills these three requirements and there is no any other grounds for refusal, it can be registered as trademark and grants protection.

\section{SINGLE COLOR TRADEMARK AND UNFAIR COMPETITION}

Unfair competition is defined as "any conduct contradicted with honorable habits established in business" (Article 98 of Iraqi Trade Law No. 149 of 1970 revoked). One sort of such contradicted conducts is to use a similar trademark of another trader without permission. (Salih, 1987, p. 168). In order to gain legal protection and prevent others people to use a trader's trademark, trademarks must be formally registered, in several countries, with the national patent office (Pinjarkar, Sharma, 2013 , p. 4425). The protection of trademarks is, mainly, to grant two objectives; first: protecting consumers from confusion about the origin of the goods; second: preventing unjust enrichment by businesses (unfair competition). This exclusivity means the exclusion of others from using the mark (Article 4.1 of the Iraqi Trademark Law). This may lead to arising problems in situations of color marks because it enforces a monopoly over a color per se and it may not be easy to determine the boundary between hindering competition in the market and the owner's exclusive right (Kudrjavaceva, 2012, p. 2). Thus, it is argued that granting an exclusive right to use the trademark may restrict open and free competition. Therefore, a balance should be kept between free and open competition and the provision of unfair competition (Peterson, 1993, p. 753). Although, over time, consumers may treat a particular color on a product as a sign to identify a brand, it can be seen that registration of color marks is less popular compared to others and only a few colors have successfully been registered. It may also depend on the business area. It is indicated that, for instance, in the United States, it is more usual to register a color trademark in certain industries such as products related to construction industry, for mechanical devices or medical products (LaLonde, Gilson, 2011, p. 186).

As mentioned above, one of the sole purposes of trademarks is the promotion of competition by preventing unfair competition. Conversely, trademarks cannot be used to inhibit competitors from selling their similar products. Therefore, it is pointed out that a trademark should not interfere with competition because it is only an exclusive right to use a mark on a product or service and not to monopolize the production of the goods or services (Summerfield, 1993, p. 973). However, trademark protection, as a kind of intellectual property, and competition may interface or overlap. It is asserted that the ECJ's decisions in L'Oreal and Lego indicate that there is still tension between trademarks and free competition (Shaw, 2009, p. 51).

Generally, there are two contemporary views which demonstrate the relationship between intellectual property rights and unfair competition. The first view prevents the interference of competition law with such exclusive property rights, even if they dominate the market, otherwise the incentive structure of innovation would be harmed. The second, the socalled theory of complementarity, states that a common goal of competition law and intellectual property rights is to enhance dynamic competition. This will be achieved only if competition law keeps the market open and allows competitors to compete with better products within competitive measures. Consequently, through this competitive process, enhancing innovation will be granted (Drexl, 2008, p. 36- 40). Furthermore, it is submitted that competition does not exist if there is no protection of intellectual property because this protection encourages competitors to develop new brands in order to take an active part in the market and consequently, competition will be promoted (Kudrjavaceva, 2012, p. 38).

The Iraqi law has followed the second view according to which a mark similar to a previously registered trademark will be refused to be registered "if registration of that mark will result in confusing the consumer public as to the goods distinguished by the mark or other similar goods." (Article 5.8 of the Iraqi Trademark law).

It shall be noted that the unfair competition was organized under the revoked Iraqi Trade Law (no. 149 of 1970). One sorts of such competition was to use a similar or a close to another trader's trademarks so that it would cause confusion with customers to differentiate the products origin. However, the current Iraqi Trade Law (no. 30 of 1984) does not contain any clauses regulating unfair competition. This is one of the loopholes in Iraqi law shall be addressed. At the meantime, the Iraqi Trademark Law does not allow registration of a sign which would lead to consumer confusion (Article 05).

Meanwhile, unfair competition shall not be mixed with consumer protection and monopoly. For the later, the Iraqi legislator has passed legislations on competition and consumer protection (Competition and Monopoly Prevention Law No. 14 of 2010; Consumer Protection Law No. 1 of 2010); however, unfair competition is beyond the subject of these legislations (Jabbar, 2017, pp. 29-34). As the result, these legislations do not regulate relations between unfair competition and trademarks protection.

In relation between these two areas of law, it is argued that this complementarity does not mean that there will be no conflict between these two intellectual property rights and competition even if they have a common goal which is dynamic competition. This is because intellectual property laws, in addition to economic goals, have certain non-economic goals in character. Therefore, it can be said that there is conflict between these two areas of law (Kolstad, 2008, p. 08).

The Treaty on the Functioning of the European Union (TFEU) in Article 102 (of Part three/ Chapter 1) states that '[a]ny abuse by one or more undertakings of a dominant position within the internal market or in a substantial part of it shall be prohibited as incompatible with the internal market in so far as it may affect trade between Member States. Such abuse may, in particular, consist: (a) directly or indirectly imposing unfair purchase or selling prices or other unfair trading conditions; (b) limiting production, markets or technical development to the prejudice of consumers; (c) applying dissimilar conditions to equivalent transactions with other trading parties, thereby placing them at a competitive disadvantage.' (Article 102 of TFEU). Accordingly, the scope of exclusivity of trademark protection is limited by the principles laid down in this Article.

The ECJ has emphasized that Article 101 and 102 of the TFEU require that competition will prevail whenever there is 
an overlap between intellectual property rights and competition, and having ownership of an intellectual property right must not lead to the conferring of a dominant position upon an economic sector. However, the evaluation of abuse of the dominant position under Article 102 plays a less important role and arguably it is believed that the Article should not be applied in relation to trademarks because trademark law can achieve the Article's purpose (Shaw, 2009, p. 51). Additionally, according to the Preamble to the Trademarks Directive, the provisions of the Directive do not exclude the application to trademarks of provisions of law of the Member States other than trademark law, including provisions relating to unfair competition (the Directive, Preamble 7).

It is obvious that the ability of other traders to market their products is limited by granting an exclusive right to the trademark owner (Article 4.1 of the Iraqi Trademark Law). It is asserted that granting such a right does not lead to the preventing of other competitors from producing the same products. However, it precludes them from selling their product under the same mark (Shaw, 2009, p. 51).

\section{The Issue of Public InTERest AND NeED TO KEEP SIGNS FREE}

The provisions of modern intellectual property laws insure that there is no unlimited intellectual property right. In other words, each of such rights is limited in scope by some techniques. One of these techniques is the refusal to register a trademark on the ground that it should be kept free for other manufactures to use. English courts assume that the monopolization which is granted by trademark registration, in addition of being anti-competitive, deprives the public of access to a limited supply of socially attractive or useful signs (Aplin, Davis, 2009, p. 260).

Neither the European legal instruments in the area of trademark (the Directive and the Regulation), the UK Trademark Act 1994, nor the Iraqi law makes an explicit reference to a need to keep free. This means that they do not contain an expression that a sign should be kept free to use by other competitors. It is indicated that Article 03(3) of the Directive has been successfully interpreted in many cases. Accordingly, any marks identified in Article 03(1) (b)-(d) will be registered if they acquire distinctiveness through use, regardless of whether the public interest wants to keep it free to other traders or not (Aplin, Davis, 2009, p. 260).

For example, in a joined case the Court of first instance refused an argument that the need to keep a sign free, for use by others, is the rationale behind Article 03(1)(b) of the Directive (SiSi-Werke GmbH \& KG v Office for Harmonisation in the Internal Market, 2004, T-146/02 to T-153/02). In addition, in Koninklijke Philips Electronics NV v Remington Consumer Products Ltd, the English courts asked the ECJ whether a special class of signs, even though distinctive in fact, were incapable of being distinctive as a matter of law (Philips Electronics NV v. Consumer Products Ltd., 2002, ECR I 5475). The ECJ ruled that Article 3(1)(a) is intended to refuse the registration only of those signs which are not distinctive. Therefore, there is no class of marks which should be refused if they have a distinctive character, either inherently or acquired through use.

Further, in Sat.1 Satelliten Fernsehen GmbH v. Office for Harmonisation in the Internal Market, the Advocate General submitted that there is no obvious reason why signs which lack a distinctive character should be kept free for general use (Fernsehen $\mathrm{GmbH}$ v. Office for Harmonisation in the Internal Market, 2004, para 28). Therefore, it is argued that, in assessing the distinctiveness of a color mark to a product or service, the need to keep colors free for general use ought to be irrelevant (Kudrjavaceva, 2012, p. 37). This approach was explicitly stated in the OHIM Case Light green/Leaf green; in this case, it was also indicated that the color light green for chewing gums is not unusual or unique; rather it is a basic color which is commonly used in this area (R 122/1998-3, Decision of the Third Board of Appeal, 2000, para 24).

However, in the Libertel case, the ECJ stated that in assessing the potential distinctiveness of a given color as a trademark, regard must be the general interest in not unduly restricting the availability of colors for the other traders who offer for sale goods or services of the same type as those in respect of which registration is sought' (Groep BV v. Merenbureau, 2003, para. 60). It is suggested that an essential concern for the ECJ is the need to keep a balance between the public interest in granting legal protection to any sign as a trademark and the need to keep certain signs free for general use (Aplin, Davis, 2009, p. 259). Allowing the registration of color marks is related to competition issues. In Libertel, it was found that not restricting the availability of colors and protecting competition are in the public interest (Groep BV v Merenbureau, 2003, para. 55). In that case, a restrictive approach was taken by the court to prevent an unjustified competitive advantage for a single competitor.

Therefore, it is argued that refusing the registration of single color marks for public interest considerations has become common. This approach might lead to the imposition of additional conditions on the registration of color marks, such as requiring the trademark owner to prove that the color mark is not only distinctive but also does not lead to unjustified competitive advantage (Kudrjavaceva, 2012, p. 42). The General Court, in KUKA Roboter GmbH, indicated that registration of a shade of orange 'would tend to prohibit competing undertakings from using any shade of orange' (Roboter GmbH v. OHIM, 2010, para. 45). This may affect competition in a negative way. It is argued that such a restrictive approach is not necessary in relation to non-traditional marks. If a mark fulfills the registration requirements, it is suitable to be registered as a trademark. In addition, color trademarks currently do not pose any threat to competition in the internal market (Kudrjavaceva, 2012, p. 44).

\section{FUNCTIONALITY}

Another important point regarding a color being registered as a trademark is the issue of functionality. A sign should not be registered if it is functional, in order to prevent it's obtaining a monopoly over functional features which are necessary to other undertakings' products or services and affect the cost or quality of their products. For instance, granting protection for a natural 
color of a product as a trademark may lead to placing competitors at a competitive disadvantage because they would be forced to color their products differently. This leads to an increase in the cost of their products in comparison to the product costs of the owner of the natural color trademark. As a consequence, increasing competition costs may lead to inhibiting competition, which is contrary to the trademark policy purposes (Summerfield, 1993, p. 973).

The position of the Iraqi law in this matter is that it only requires that registration of a mark shall not cause confusion with consumer public. (Article 05 of the Trademark Law).

Therefore, if trademark protection is granted to functional features, other competitors may not be able to compete effectively. Color may serve functional purposes when it is communicating information about the product. For example, the color blue communicates 'coolness' or the color white 'clean'. In addition, it can serve some utilitarian functions such as the color grey for surgical instruments. Furthermore, color is also functional if it is used to indicate the grade of a product or if purchasers prefer the product in one color over other colors (Neal, Butler, 1995, p. 71). The latter means that the consumer purchases the product because of the aesthetic functionality of its color which may hinder competition (Summerfield, 1993, p. 973).

\section{COLOR EXHAUSTION OR COLOR DEPLETION THEORY}

According to this theory, if a color is registered as a trademark by undertaking, other traders will seek to register the remaining colors and soon all colors will be taken. As a result, this leads to preventing new competitors from entering the market. In Diamond Match v. Saginaw Match, the US court stated that ' $[t]$ he primary colors, even adding black and white, are but few. If two of these colors can be appropriated for one brand of tipped matches, it will not take long to appropriate the rest.'(Match v. Match Co, 1906, 142 F. 727). Then, competitors will not be able to market a product when all the colors for covering the goods are gone (Match v. Match Co, 1906, $142 \mathrm{~F}$. 727). The OHIM Board of Appeal, in the William Wrigley Junior case, made it clear that depriving the market from its rich diversity of colors is not consistent with the purpose of trademark protection ( $\mathrm{R} 122 / 1998-3$, Decision of the Third Board of Appeal, 2000, para 30).

In another US case, Qualitex, the court rejected the argument of prohibiting the registration of a single color on the ground of color depletion (Qualitex Co. v. Prods. Co., 1995, 514 U.S. 159). In the court's view, hundreds of shades of colors are produced and thousands of additional colors can be manufactured by mixing existing colors. However, it is argued that this analysis is not helpful, since consumers do not have the opportunity to compare the shades of two or more similar products, on the one hand. On the other hand, although there are hundreds of colors or shades, the majority of consumers know little of them (Jackson, 2008, p. 91).

In the Libertel case, it was expressed that ' $[\mathrm{t}]$ he number of colors which the public is capable of distinguishing is limited, because it is rarely in a position directly to compare products in various shades of color' (Groep BV v. Merenbureau, 2003, para. 47). Consequently, in order to avoid consumer confusion and prevent violating a protectable color trademark, competitors may not be able to choose a color from these broad bands of available colors. Therefore, this seems to prevent them from competing effectively (Jackson, 2008, p. 91).

Furthermore, even if a massive number of colors are available, it can be argued that only a limited number of them are desirable within any given industry. Thus, new competitors will be at a disadvantage if all desirable colors for a certain category of products are registered as trademarks (Jackson, 2008, p. 91). Therefore, they cannot enter the competitive market effectively.

However, it is suggested that relying on competition considerations in assessing the eligibility of a mark may result in making the registration and protection of color marks completely impossible. In addition, it would be unfair to refuse registration of a color on the grounds of lack of availability of colors because the trademark proprietaries usually invest a lot of money and time to make their mark capable of identifying the origin of the product (Kudrjavaceva, 2012, p. 44).

\section{CONCLUSION}

The world markets are currently experiencing an increasing number of applications to register non-traditional marks with the aim of capturing the attention of potential consumers and to serve the basic goal of identifying products or services. As a matter of law, traditional and non-traditional marks are treated in the same way. Colors can satisfy the requirements to be considered signs, to be graphically represented and to be capable of distinguishing the products of one undertaking from those of other traders.

In response to the need for registration of non-traditional trademarks, the Iraqi Trademark Law was amended in the year of 2004 so that to allow registration of such marks. Colors are one of these not-traditional signs which are allowed to be registered by the amended law. Moreover, it requires signs to have a distinctive character, either inherently or acquired through use, by which it has expanded grounds for trademarks registration. These are considered as most advantages of the law amendment. However, it does not explicitly refer to registration on "a single color" as a trademark. In combination of article 01 and 05 of the law, it might be argued that the Iraqi law allows registration of a single color if it will not result in confusing the consumer public as to distinguish the goods origin.

On the other hand, protection of trademarks is main aim of such registrations. One of the sole purposes of trademark protection is to eliminate unfair competition and stimulate fair competition by granting an exclusive right to the trademark owner to use the mark and prevent other competitors from using it, in relation to their products or services. While trademarks are mainly pro-competitive by identifying the origin of the products (Torremans, 2010, p. 389), the situation, however, seems to be different when it comes to color marks. There is no unified attitude regarding the effects of single color marks on competition. Therefore, as discussed above, even courts' decisions on this issue are not consistent. Many registration applications for single color marks have been refused on the 
ground that they may contradict the purposes of trademark protection, including the promotion of competition.

It is noted that there is a loophole in the Iraqi legislations in regard of regulation of unfair competition. The currently in force laws do not include any provision how trademarks are effected by unfair competition. The Iraqi Trademark Law addresses the issue in only one place where registration of a trademark would be refused if it is identical or similar to a previously registered trademark.

It is submitted that courts are not allowed to recognize a core of protected signs. In addition, at the time when the substantive law of the Directive was adopted, there was a clear idea that strong intellectual property rights enhance competition rather than inhibiting it (Aplin, Davis, 2009, p. 261). Therefore, in disputes involving these marks, courts must balance the need to maintain competition with the need to respect trademark rights and, above all, to protect the public from deception and confusion.

Generally, trademark rights are not supposed to overlap with competition. Nonetheless, registration and protection of single color trademarks allows traders to lock up the aesthetic and communicative attributes of colors, and therefore inhibits legitimate competition, to the detriment of consumers and competitors. Thus, single color marks are often used effectively for commercially disadvantaging competitors because this leads to signifying sources singularly (Bartow, 2009, p. 263).

Further, competitors may feel forced not to use a similar shade of a registered color trademark because they may possibly be claimed for violation of the protected color mark and this leads to put them in a competitive disadvantage.

Finally, it might be argued that, coupled with the uncertainties and the risks of color exhaustion, the anticompetitive effects of color monopolies outweigh any possible social benefit from a regime that permits the registration of single color trademarks. Therefore, allowing the registration of single colors as trademarks should be restricted in order to stimulate competition.

\section{RECOMMENDATIONS}

1. The present study recommends the Iraqi legislator to clarify whether registration of a single color as a trademark is allowed.

2. The Iraqi legislator is highly urged to pass "Unfair Competition Law" as currently there is loophole in this matter.

3. It is necessary to determine methods of protection of nontraditional trademarks, and effects of unfair competition on single color trademarks.

\section{REFERENCES}

\section{Legislations and Treaties:}

The Agreement on Trade Related Aspects of Intellectual Property Rights (TRIPS) 1995.

The UK Trademarks Act 1994.
The Iraqi Trademark and Geographical Indications Law No. 21 of 1957 (as Amended in 2004).

The Iraqi Competition and Monopoly Prevention Law No. 14 of 2010.

The Iraqi Consumer Protection Law No. 1 of 2010.

The Iraqi Trade Law No. 149 of 1970 (revoked).

The Iraqi Trade Law No. 30 of 1984.

Directive (2008/95/EC). The Laws of the Member States Relating To Trademarks. L 299/25.

Council Regulation (EC) No. 207/2009 on the Community Trademark. L78/1.

Treaty on the Functioning of the European Union. (1957). Part Three: Union Policies and Internal Actions - Title Vii: Common Rules on Competition, Taxation and Approximation of Laws.

\section{Cases:}

Koninklijke Philips Electronics NV v. Remington Consumer Products Ltd. (2002). Case 299/99. ECR I - 5475.

Libertel Groep BV v. Benelux-Merenbureau. (2003). Case C-104/01. ECR I3793.

Ralf Sieckmann v. Deutsches Patent- und Markenamt ('Methylcinnamat'). (2002). Case C-273/00. ECR I-11737.

Sat.1 SatellitenFernsehen $\mathrm{GmbH}$ v. Office for Harmonization in the Internal Market. (2004). Case C-329/02 P.

Canon Kabushiki Kaisha v Metro-Goldwyn-Mayer Inc. (1998). Case C-39/97. ECR I-05507.

Decision of the Third Board of Appeal. (18 December 2000). Case R 122/19983.

Orange Personal Communication Service Ltd, Third Board of Appeal OHIM (February 12, 1998). Case R 7/97-3. ETMR 337.

Decision of the Fourth Board of Appeal. (28 August 2002). Case R 785/20004.

KUKA Roboter GmbH v. OHIM. (2010). Case T-97/08. C 301/41.

Diamond Match v. Saginaw Match Co. (1906). 142 F. 727 (6th Cir.).

Freixenet, SA v. OHIM. (2010). Case No. T-110/08.

Deutsche SiSi-Werke GmbH \& Co. Betriebs KG v. Office for Harmonization in the Internal Market, Court of First Instance. (2004). Joined Cases T$146 / 02$ to $\mathrm{T}-153 / 02$.

Qualitex Co.v. Jacobson Prods. Co. (1995). 514 U.S. 159.

Societe des Produits Nestle SA v. Cadbury UK Ltd. (2012). EWHC 2637.

\section{Books:}

Basm Mohamad Salih. (1987). Commercial Law: Part One, General Theory on Traders and Commercial Contracts, University of Baghdad.

Josef Drexl. (2008). Research handbook on intellectual property and competition law (Cheltenham Edward Elgar).

Kolstad O. (2008). Competition law and intellectual property rights - outline of an economic-based approach.

Tanya Aplin and Jennifer Davis. (2009). Intellectual Property Law: Text, Cases, and Materials (1st Edition, OUP).

Torremans T, Holyoak and Torremans. (2010). Intellectual Property Law. (6th Edition, OUP). 


\section{Articles:}

Bartow A. (2008). The True Colors of Trademark Law: Green lighting a Red Tide of Anti Competition Blues. 97 Ky L J. Retrieved from https://scholars.unh.edu/cgi/viewcontent.cgi?referer=https://www.google .com/\&httpsredir $=1 \&$ article $=1295 \&$ context=law_facpub (last visited January 03, 2020).

Jekaterina Kudrjavaceva. (2012). Issues surrounding registration of Color trademarks. RGSL Research Papers No. 9 ISSN 1691-9254. Retrieved from https://www.rgsl.edu.lv/uploads/research-papers-list/14/rp-9kudrjavceva-final.pdf (last visited January 03, 2020).

Labadie-Jackson G. (2008). Through The Looking Hole of The Multi-Sensory Trademark Rainbow: Trademark Protection of Color Per Se Across Jurisdictions: The United States, Spain And The European Union. 7 Rich J Global L \& Bus.

LaLonde A G and Gilson J. (2011). Getting real with non-traditional trademarks: what's next after red oven knobs, the sound of burning methamphetamine, and goats on a grass roof? 101 TMR.

Neal S and Butler C. (1995). It's Time to End Discrimination against Trademarks of Color. 5 Fed Cir B J.

Nigam, Akriti \& Garg, Arpit \& Tripathi, R. (2011). Content based Trademark Retrieval by Integrating Shape with Color and Texture Information. International Journal of Computer Applications. Volume 22- No.7.
Peterson K L. (1993). Master Distributors, Inc. v. Pako Corporation: The Eighth Circuit Refuses to Adopt a Per Se Prohibition on Trademark Protection of a Single Color. 70 Iowa L Rev.

Pinjarkar, L., \& Sharma, M. (2013). Content Based Image Retrieval for Trademark Registration: A Survey. International Journal of Advanced Research in Computer and Communication Engineering, Issue-11, Vol. 2. Retrieved from https:/www.ijarcce.com/upload/2013/november/53-sLatika_-content.pdf (last visited January 04, 2020).

Shaw K. (2009). Likelihood of Coexistence: A Comparative Analysis of the Interplay between European Trademark Law and Free Competition. $18 \mathrm{U}$ Balt Intell Prop L J.

Summerfield C. (1993). Color as a Trademark and the Mere Color Rule: The Circuit Split for Color Alone. 68 Chi Kent L Rev.

\section{Research Papers:}

Lara Adil Jabar. (2017). Competition Protection in Telecommunications sector. Master Thesis presented to College of Law, University of Sulaimani, Kurdistan Region of Iraq. 